\title{
Statsløs i diaspora: kulturarvdokumentasjon og virtuelt museum
}

HACI AKMAN*

Title: Stateless in a diaspora: documenting cultural heritage and the virtual museum.

Abstrakt: The museum as a social arena accentuates cultural encounters between individuals in unequal situations that are played out in public. Meetings between cultures are in themselves not a new phenomenon, but increased globalisation and immigration impel us as researchers of culture to repeatedly question our notions of ethnicity, cultural heritage and diaspora. This article is based on the Norwegian-Kurdish Heritage Documentation project, which has been supported by the Norsk Kulturraid (Arts Council Norway) for two periods.

The project consists of two phases. Phase I was designed to document and collect tangible and intangible cultural elements among the Kurds in the diaspora. In Phase II, which is based on the first phase, the collected materials are sorted, categorised and analysed with the intent to publish a Kurdish virtual (online) museum. The virtual communication form adapts to the conditions that life in the diaspora requires for communication and preservation of culture.

In this article, the terms "stateless" and "diaspora" are used. The question is whether a virtual museum can be a useful tool for cultural heritage dissemination for a stateless people in a diaspora context who are otherwise unable to communicate their culture through physical institutions.

Key words: Stateless, diaspora, Kurds, cultural heritage, virtual museum.

\section{INNLEDNING OG PROBLEMSTILLING}

Norsk-kurdisk kulturarv dokumentasjonsprosjekt (NKKD) ${ }^{1}$ startet høsten 2004, med støtte fra Norsk Kulturråd. ${ }^{2}$ Prosjektet innbefattet kartlegging av møter mellom nordmenn og kurdere før og nå. Datainnsamlingen foregikk i Norge, Sverige, England og Belgia, men det har også vært tatt kontakt med privatpersoner og kulturorganisasjoner i Frankrike og Tyskland i kartleggingsøyemed. Materialet som ble samlet inn ble grunnlaget for neste fase i prosjektet som fikk navnet Norsk-kurdisk virtuelt museum (NKVM). Det virtuelle museets hen- 
68 sikt er å være en kunnskapsbase for kurdere i diaspora, men også for nordmenn og andre med interesse for kurdernes situasjon. En målsetting er at "besøkende" gjennom deltakelse i interaktive, multimodale aktiviteter i verkstedet, får kunnskap om kurderne, Kurdistan og hva det vil si å leve i diaspora på godt og vondt. I tillegg til faktakunnskap, er det et mål at NKVM presenterer de positive sidene ved å være et folk som er representert i de fleste deler av verden. Hovedfokuset i det virtuelle museet rettes likevel mot kurdere i Norge, og deres integrasjon i det norske samfunnet; hjem, skole, arbeid og samfunnsliv.

Fra 1960-tallet og fremover kan vi se fremveksten av virtuelle formidlingsstrategier innenfor arkiv, bibliotek og museum. Virtuelle museer blir definert som en samling av elektroniske gjenstander, og fungerer som informasjons- og kunnskapsbase. Virtuelle samlinger kan inneholde nesten hva som helst, men vanligvis består de av billedkunst, tegninger, fotografier, diagram, lydopptak, videosegmenter, avisartikler og kanskje også transkripsjoner av intervju. Materialet håndteres og lagres i databaser (McKenzie 1997). Det unike ved et virtuelt museum, er at det gjør det mulighet å nå et publikum uavhengig av geografisk tilknytning.

Interessen for å bruke interaktive applikasjoner og multimedia innen museumsfeltet, ble vekket i 1991 på "The International Conferences of Hypermedia and Interactivity in Museum (ICHIM)" (Schweibenz, 1998). Her ble det slått fast at museer er institusjoner som formidler og bevarer kunst, kultur og vitenskap i form av fysiske gjenstander. For statsløse folkegrupper, som kurderne, som av politiske, sosiale og kulturelle årsaker ikke har hatt mulighet til å opprette fysiske kulturinstitusjoner i form bibliotek, museum eller arkiv, enten som følge av krig og forfølgelse i hjemlandet, eller fordi en reorganisering av museumsfeltet blir for vanskelig å organisere i diaspora, blir det virtuelle museum en alternativ måte å ivareta kulturarven på. Diaspora kjennetegnes av religiøse og nasjonale grupper som lever utenfor sitt hjemland eller historiske kulturområde.

Intensjonen med denne artikkelen er å beskrive prosjektet og målgruppen, kurderne, vise til historiske møter mellom nordmenn og kurdere, løfte fram noen utfordringer i feltet, og si noe om hvordan internett kan benyttes som kunnskapsbase og kommunikasjonssystem for et statsløst folk i diaspora. Diaspora kjennetegnes ved at det aktualiserer spørsmål om identitet som noe som er forankret i et forestilt samfunn, men som også tar utgangspunkt $\mathrm{i}$ et større globalt samfunn og ulike nettverk. Dette aktualiserer spørsmålet Hvordan kan en virtuell formidlingsform vare et redskap for statslose folkegrupper $i$ diaspora til a formidle sin kultur?

\section{KURDERNE: ET STATLøST FOLK?}

I følge Norsk Organisasjon for Statsløse Mennesker (NOSM) kan statsløse defineres som følger:

[...] mennesker som er ikke juridisk anerkjente borgere av noen stat (de jure statsløshet). FNs Høykommissæren for Flyktninger (UNHCR) anslår antallet statsløse mennesker i verden i dag til å være cirka 11 millioner. Fordi de ikke har noen statsborgerskap blir statsløse mennesker frarøvet grunnleggende rettigheter som retten til bosetting, retten til eiendom, retten til arbeid og retten til utdanning i mange land. Internasjonalt lever ofte statsløse mennesker $\mathrm{i}$ et rettsløs vakuum, i akutt nød og uten diplomatisk beskyttelse. Statsløshet har blitt betegnet som "the right to have no rights". ${ }^{3}$ 
Det finnes i følge NOSM mange folk som i dag betegnes som statsløse. "Mens statsløshet forekommer i alle verdensdeler omfatter territorier med en stor statsløs befolkning blant andre Palestina, Burma, Nepal, Thailand, Libanon, Sri Lanka, Bangladesh, Kuwait”. Dette må kalles en smal forståelse av statsløshet. I virkeligheten kan selv personer og grupper som anerkjennes som borgere av en stat, bli statsløse. Mange folkegrupper, deriblant kurderne, anerkjennes kun i den grad de er villige til å gi avkall på egen etnisk identitet, avstår fra å kalle seg et folk, eller krever rettigheter som et folk. Kurderne i Syria faller inn under den første (smalere) juridiske definisjonen, de har verken borgerrettigheter, pass, eller identifikasjonsdokumenter. Den andre videre forståelsen vil også omfatte kurderne i Tyrkia, og kurderne i Iran. Hovedgruppen av kurderne som befinner seg i diaspora, uavhengig av hvilken stat de lever innenfor, er kommet som følge av politiske forhold hvor de, med unntak av Irak etter Saddam Husseins fall i 2003, ikke anerkjennes som et folk. Kurderne er i disse landene fratatt grunnleggende rettigheter som folk og har av samme grunn ikke mulighet til å fremme sin kultur i den staten de lever i, eller har forlatt. I denne artikkelen gjør jeg ingen distinksjoner mellom de to forståelsene av statsløshet. For å forstå hva som kjennetegner kurderne som folk vil jeg gå litt tilbake i historien, for så å si noe om dagens situasjon.

I følge Kariane Westrheim (2009) har spørsmål om hva som er Kurdistan alltid vært gjenstand for hete og kontroversielle debatter. I et historisk perspektiv hevder Paul White (2000) at der også synes å være uenighet blant forskere om hvem kurderne er, selv om det er en slags enighet om at kurderne i uminnelige tider har bebodd et geografisk område kjent for dem selv og andre som Kurdistan (sitert i
Westrheim 2009, s. 16). Navnet Kurdistan har vært i bruk siden 1300-tallet men ble først utbredt på 1600-tallet. David McDowall (2000), hevder imidlertid at det har eksistert kurdiske samfunn allerede for 2000 år siden, mens Izady (1992, p. 28) mener at disse kan spores ennå lenger tilbake til pre-historisk tid. I følge Hakan Özoglu (1996), ble betegnelsen "kurder" først brukt i det sekstende århundre for å kunne referere til en kollektiv identitet. Han viser til et kjent litterært dokument Serefname: skrevet av den kurdiske forfatteren Serefhan Bitlisi (1543-1599), en kurdisk hersker fra Bitlis-emiratet. ${ }^{4}$ Boken demonstrer en velutviklet forståelse av kurdisk identitet. Mens Serefhan bruker betegnelsen "kurder" bevisst, gir han ingen klar definisjon av betegnelsen, han forstår betegnelsen kurdisk som kollektiv identitet, nært assosiert med en geografisk region kalt Kurdistan (Özoglu, 1996, s. 9). Stammesamfunnet, som var den sentrale organisatoriske enhet i kurdisk liv, definerte medlemmene som kurdere. Uten denne stammetilhørigheten, ble personene definert som ikke-kurdere og utenforstående (Akman, 2002, p. 103).

Det kurdiske folk lever splittet mellom Tyrkia, Syria, Iran, Irak og et mindre antall i de armenske områdene. Der er trolig 30 millioner kurdere i Midtøsten (Yildiz, 2005. p. 4), mer enn halvparten lever i Tyrkia. Som en følge av krig, politisk uro og vanskelige levekår i disse landene, har det foregått betydelige kurdiske vandringer, mellom de statene der kurderne bor, men mange har også flyktet eller forlatt disse landene av andre årsaker. Som en følge av denne spredningen bor det $\mathrm{i}$ dag rundt åtte millioner kurdere i ulike diasporaland, deriblant rundt 45000 i Skandinavia, hvorav de fleste bor i Sverige. De fleste mennesker oppfatter seg selv som tilhørende en spesifikk nasjon, eller et avgrenset område el- 
70 ler territorium. Det gjør også de fleste kurdere, men på grunn av splittelsen blir kurderne av mange forskere definert som statsløse. I følge Amir Hassanpour (1994) er det kurdiske folk en av de største statsløse nasjoner i verden.

\section{MANGEL PÅ FYSISKE INSTITUSJONER - EN FØLGE AV STATSLØSHET}

Mange kurdere, som kanskje aldri har vært i Kurdistan, kan likevel ha en mental forestilling om dette hjemlandet (Westrheim 2005). Statsløs diasporaidentitet referer gjerne til de adskilte segmenter av en nasjon som ikke har vært i stand til å etablere sin egen fysisk uavhengige stat (Sheffer 2003). Splittelsen av det kurdiske folk, og mangelen på et lovfestet geografisk rom som er internasjonalt anerkjent, gjør at dialogen rundt kulturarv, kulturminne og kulturvern mangler kontinuitet. Organisering og ivaretaking av kulturarv blir i slike tilfeller desto mer komplisert. Av samme grunn har det vist seg at det er vanskelig for kurderne å samle og organisere den faglige kompetansen i hjemlandet og i diaspora.

Tilgjengeliggjøring av digitale bilder, lydfiler, tekstdokumenter og andre data med historisk, vitenskapelig og kulturell informasjon, er et potensial for diasporasamfunn som av ulike årsaker ikke kan, eller får tillatelse til å etablere fysiske institusjoner.

The concept of the Virtual Museum demonstrates how limitations imposed by the traditional method of organizing and presenting information can be overcome in the context of museum visits. In a nutshell, the Virtual Museum provides multiple levels, perspectives, and dimensions of information about a particular topic: it provides not only multimedia (print, visual images through photographs, illustrations or video, and audio), but, more important, it provides informa- tion that has not been filtered out through these traditional methods (Hoptman 1992, s. 146).

Selv om Hoptman (1992) ikke relaterer virtuelle museer til statsløse folk, ser vi likevel her at et virtuelt museum innehar muligheter som ikke finnes i det tradisjonelle museet. Når gjenstander ikke kan flyttes, eller er fysisk utilgjengelige, kan et foto eller en videosnutt skape forestillingen av tilgjengelighet. Når dette også omfattes av identitetsmarkører, vil kurdere oppleve gjenstanden eller boken som tilhørende sitt folk, eller landskapet som sitt territorium.

Myndighetene i Tyrkia, Syria og Iran vil neppe tillate kurdiske kulturvitere, kunstnere, eller intellektuelle innenfor ulike felt å etablere kulturorganisasjoner eller museer, nettopp på grunn av den sterke identitetsskapende og ikke minst samlende funksjon som knyttes til disse. I Norge har museet og andre kulturorganisasjoner vært en vesentlig kilde i nasjonsbyggingsprosessen. Det er nettopp slikt myndighetene i undertrykkende regimer, som Tyrkia overfor kurderne, frykter. Det samme er tilfelle i Syria, der kurderne ikke engang har identitetskort og langt mindre et statsborgerskap. Et stort antall kurdere sitter fengslet av "politiske" årsaker, som kan være organisering av en musikkfestival, at de har forfattet noe på kurdisk eller arrangert en kunstutstilling. Kurderne i Irak bor i den nordlige delen, i den autonome kurdiske regionen nå kalt Kurdistan (Kurdistan region). Etter 2003 har situasjonen for kurderne gradvis forbedret seg $\mathrm{i}$ denne delen. Etter den massive undertrykkelsen under Baath regimet og Saddam Hussein, er kurderne her $\mathrm{i}$ ferd med å etablere egne institusjoner, også innen museums- og kulturfeltet. Det finnes til og med et folkemordmuseum, til minne om alle dem som ble 
utryddet under det foregående regimet. Oppbygging av samfunnsinstitusjoner som blant annet museet, er et ledd i en mental gjenoppbyggings- og helbredelsesprosess - også for kurdere i diaspora. På tross av dette møter kulturarbeidere utfordringer når det gjelder kartlegging, innsamling, og registrering av kulturminner. Mangel på erfaring, kompetanse og samorganisering, gjør arbeidet vanskelig og lite effektivt. Mange områder er fortsatt minelagt og setter kulturarbeider i fare. Også i Iran ser vi mange av de samme erfaringene og utfordringene. Iran benekter ikke eksistensen av kurdere, ei heller at den østlige delen kalles Kurdistan, men likevel legges hindringer i veien for at kurderne skal få en autonom region. For kurderne i disse statene, og ikke minst kulturarbeidere, vil et virtuelt museum representere en mulighet for formidling av kulturarven. Selv om internett-tilgang fortsatt er et problem i noen områder, er ikke dette lenger den største hindringen.

Bruk av elektronisk medier i kulturformidling vil fortsatt for noen kunne oppleves som en trussel mot det fysiske museet. Og selvsagt er det annerledes - ikke minst fordi man ikke kan lagre virkelige og sanselige objekter. På den annen side kan heller ikke det tradisjonelle museet gjøre alle sine gjenstander tilgjengelige for publikum til enhver tid. Kulturhistoriske gjenstander blir liggende lagret i ulike magasiner, og hvorvidt de noen gang blir tilgjengeliggjort for publikum avhenger av hva konservatorer ønsker å formidle. Et sentralt argument for å opprette et virtuelt museum, er at det gjør kulturarvmateriale tilgjengelig $\mathrm{i}$ en globalisert verden, om enn $i$ en annen form. Norge er i økende grad et mangfoldig og flerkulturelt samfunn. De personer og etniske grupper som er kommet hit, har med seg et kulturarvmateriale. Dette kan være gjenstander, men også tradisjoner, fortellinger og minner som kan ha betydning i bevaring av kultur. I håndteringen av pluralistisk ${ }^{5}$ kulturarv må det derfor åpnes for at gjenstander ikke bare kan formidles i fysisk form i et fysisk museum, men også kan formidles på ulike måter i et virtuelt museum.

\section{FORANKRING I STED: HJEMLAND OG} DIASPORA

Det å arbeide med pluralistisk kulturarv i diaspora utfordrer oppfatningen av gjenstanders forankring til sted, eller hjemland. Begrepet diaspora stammer fra latinske "dia" (på tvers) og "sperien" (spre seg, spre). Betydningen knyttes opp mot mennesker og folkegrupper som har forflyttet seg, frivillig eller ufrivillig, fra sitt opprinnelige hjemland. Diaspora betraktes ofte som en tilstand preget av separasjon fra en opprinnelse, og usikkerhet på fremtiden. På den annen side kan diaspora også inneha et håp om en ny begynnelse et annet sted (Braziel \& Mannur 2003). Diaspora fører ikke automatisk til brudd med landet du kom fra, eller assimilasjon i landet du kommer til (Brubaker 2005). Mennesker i diaspora lever i en transnasjonal tilstand - både "der og her" - der sosiale relasjoner til hjemlandet inngår i relasjonene og det sosiale og kulturelle livet i diaspora (Wahlbeck, 2002),

Et samfunn oppfattes gjerne i relasjon til et sted. Hvordan ett folk er knyttet til et bestemt territorium nedfelles i immaterielle og materielle uttrykk av kulturen. Som nevnt kan hjemlandsidentiteten være relatert til et "mytisk" sted, som en knytter fantasi, drømmer og lengsler til. Men diaspora er samtidig et kulturelt og politisk terreng der individuelle og kollektive minner møtes, settes sammen igjen og rekonstrueres. Mye tyder på at lengselen etter 
72 et hjemland er et sentralt aspekt ved kurdernes diasporanarrativ. Et narrativ er en fortelling der både det lokalt kjente, og globalt ukjente inngår. For å gjøre verden begripelig, skape fellesskap, konstruere og reforhandle identitet, gjør mennesker bruk av fortellinger. Når disse knyttes opp mot større diskurser, for eksempel fortellingen om Kurdistan og det kurdiske, blir de til narrativer. Fortellingene blir et verktøy som den enkelte kan plassere seg innenfor i en større, felles historie.

Slike diasporanarrativ handler ofte om hjem. "Hjem” er i følge Avtar Brah (1996) definert som et mytisk sted som er forankret i forestillingene til diasporamigranten. Som nevnt over dreier diaspora seg også om kontakten med hjemlandet og den identitet som er knyttet til det. Man kan tenke seg at den kurdiske migranten forholder seg til tre nivå av stedsidentifikasjon; hjemlandet Kurdistan, vertslandet og diasporaidentitet, som innebærer en vekselvirkning mellom de to øvrige forhold. Karakteristisk for diasporaidentitet er solidaritet til egen gruppe, og et forestilt hjemland. I tilfeller der gruppen opplever seg truet kan den gi seg utslag i mobilisering av den etniske identiteten. Opprettelsen av kurdiske kulturelle og politiske organisasjoner i diaspora er et eksempel på dette. Til tross for at disse organisasjonene gjerne har et kulturelt og politisk fokus, vil de ikke kunne stå for eller organisere innsamling, registrering, bevaring og formidling av materiell eller immateriell kurdisk kulturarv.

De virtuelle båndene som definerer transnasjonale, kulturelle og politiske rom er viktige aspekt ved overlevelsen av kurdisk identitet. I følge Doreen Massey (1994), kan samfunn overleve selv om de ikke eksisterer på samme sted. Den følelsesmessige tilknytning til sted er viktigere enn den fysiske eller territorielle tilknytning. Robin Cohen (1997) hevder at diaspora kan rekonstruere det kulturelle minnet gjennom gjenstander og felles forestillinger.

\section{FASE I: DOKUMENTASJON AV KURDISK KULTUR I DIASPORA}

Mennesker som flytter kommer fra ulike bakgrunner, men de har det til felles at de har med seg noe fra hjemlandet. NKKD hadde som formål å samle inn kulturarvmateriale, og i tillegg dokumentere ulike kulturmøter i diaspora. Intensjonen var å la dette danne grunnlaget for et norsk-kurdisk virtuelt museum. Første fase av prosjektet dreide seg altså om kartlegging av kulturmøter mellom kurdere og nordmenn i fortid, nåtid og fremtid, og å registrere kulturarvstoff $\mathrm{i}$ form av gjenstander, foto, filmopptak, litteratur, personlige fortellinger og minner. Det ble gjort intervjuer i Norge, Sverige, England og Belgia, i de samme landene ble det også samlet inn gjenstander, eller dokumentert slike. Det ble også samlet inn fortellinger, personlige minner og gjort opptak av tradisjonelle sammenkomster og kulturbegivenheter. I tillegg ble det tatt bilder av nasjonaldrakter fra de ulike delene av Kurdistan.

Det var en metodisk utfordring å få oversikt over kurdiske kulturelementer i diaspora, samt å få kunnskap om historiske møtepunkt mellom kurdisk og norsk kultur. Selv om det finnes litteratur om dette, er mye av denne kunnskapen formidlet gjennom fortellinger. Derfor ble det viktig å finne informanter som kunne si noe om dette. Dokumentasjon av kulturmøter mellom nordmenn og kurdere kan være en kilde til forståelse av kurdisk diasporakultur i Norge fordi felles minner gir felles identitet og trekker paralleller til kulturarv i tid og rom. Feltarbeidet besto i hovedsak i å samle 
inn og dokumentere ulike elementer i kurdisk kulturarv som fantes i diaspora, som historie, geografi, kunnskap og erfaringer, kulturelle verdier, meninger, mentalitet, væremåte, dagligliv og folklore. Den materielle kulturen som ble samlet inn består av elektronisk dokumentasjon av gjenstander, billedmateriale og dokumentasjonsfilmer. Den immaterielle kulturen ble tatt opp på lydfil og CD-rom. Opptak er gjort av personanekdoter og fortellinger. Videoopptak er gjort av feiringer, visning av nasjonaldrakter, matlaging og tradisjonelle sammenkomster.

$\AA$ etablere gode og tillitsfulle relasjoner til personer og organisasjoner med kunnskap om kurdisk kultur har vært en forutsetning for å lykkes med dette prosjektet. Utgangspunktet var å opprette nettverk av informanter som kunne bidra med kunnskap om kurdisk historie, kultur og politikk, men som også enten selv hadde samlet gjelstander, eller som kjente til noen som gjorde det. Vi søkte også informanter som kunne introdusere oss til familier og hjem som levde det vi, med fare for å kategorisere, ville kalle "tradisjonelle kurdiske liv" der tradisjon, og kanskje også religion var av stor betydning i dagliglivet. Kulturinstitusjoner og ulike organisasjoner i diaspora som representerte ulike deler av Kurdistan, har vært viktige bidragsytere i dokumentasjons- og innsamlingsprosessen. For å finne frem til gode informanter, for å få vite noe om hvor det var best å starte, hva som var viktig å samle inn, hvordan ulike kulturelementer kunne samles og oppbevares, så vi på erfaringer som var gjort fra liknende prosjekt internasjonalt. I dette prosjektet kom vi i kontakt med jødisk og afrikansk dokumentasjonserfaring, ${ }^{6}$ og besøkte utstillinger fra deres prosjekt, i dette tilfellet i England. Folk og etniske grupper i diaspora er forskjellige, men de har også mange fellestrekk som kanskje særlig dreier seg om hvordan opprettholde det kulturelle særpreg, tradisjoner, språk, men også kontakten med "det opprinnelige", med hjemlandet og relasjoner der. Det er også viktig for mange å kjenne historien bak flyttingen og flukten, men også å få kunnskap om hvordan det er i hjemlandet nå. Da blir historie og politiske forhold viktige. Slik kan ulike gruppers dokumentasjonsinitiativ være til gjensidig nytte og inspirasjon, ikke minst når det gjelder å utveksle kunnskap og erfaring. Jødene i England, men også personer med afrikansk bakgrunn som har lang botid i Storbritannia, har erfaringer vi i Norge ikke har gjort. Slike erfaringer dreier seg ofte om relasjoner og daglig-liv i det mange fortsatt vil kalle vertslandet, men erfaringer dreier seg også om historisk bakgrunn, flukt og tradisjoner.

Kurdere i diaspora har ofte en sterk følelsesmessig forankring til det hjemland de kaller Kurdistan. I prosjektet har det av samme grunn vært viktig å ta utgangspunkt i materielle gjenstander som de husker fra hjemlandet og som derfor får stor betydning i diaspora. Mange kvinner i diaspora syr kurdiske drakter til seg selv, barna og kjente. Draktene lages slik man husker, eller har lært å sy dem. Stoff og tilbehør får kvinnene når de besøker hjemlandet, eller fra kjente som har vært på besøk der. Disse draktene blir reprodusert slik de husker dem, eller etter bilder eller mønstre. Det finnes også eksempler der drakten tilpasses mer moderne design, men med typiske kurdiske draktelementer. Uansett blir drakten som produseres i diaspora en skapelse, en "rekreasjon" av den tradisjonelle og det mange ville kalle "autentiske" drakten.

Et sentralt funn i dokumentasjonsprosjektet er at det i særlig grad er gjenstander og artefakter som bidrar til å understreke kurdernes 
74 tilknytning til et sted. Drakter, tepper, natur og kulturlandskapsbilder, bilder av nasjonaleller frigjøringshelter, keramikk, musikk, mattradisjoner, og litteratur er typiske innslag og svært viktige artefakter i kurdiske hjem i diaspora.

\section{FASE II: ET VIRTUELT MUSEUM}

Et viktig formål med NKVM (Norsk-kurdisk virtuelt museum) er først og fremst representativitet; å etablere et museum som kan representere kurdere fra alle deler av Kurdistan, ${ }^{7}$ slik kan det virtuelle museet fungere som en arena for gjenkjennelse og bevisstgjøring uavhengig av nasjonale grenser (mellom kurdere) og politiske skillelinjer. For det andre er det viktig å se på kompleksiteten i diaspora på et mer generelt grunnlag. Den konstante påvirkningen kurderne utsettes for som følge av tvungen migrasjon, integrasjon, assimilering og adskillelse gjør at den kurdiske kulturen er utsatt og sårbar. Som andre statsløse folk og grupper har kurdere en sterk bevissthet om sin kurdiskhet, men er ofte usikre på hvilket innhold denne identiteten skal ha. En 17-årig kurdisk jente kan ha vansker med å identifisere seg med foreldrenes kulturelle verdier, men har ingen problemer med å identifisere seg med sin norske vennegjeng, og vice versa. Men diasporatilværelsen kan også by på store utfordringer for identiteten, i form av ekskluderingsmekanismer som eksisterer i vertssamfunnet; som rasisme og forskjellsbehandling. I noen tilfeller blir dette så fremtredende at den eller de som utsettes for det trekker seg tilbake, noe som hindrer en fornuftig integrasjonsprosess. For å klargjøre dette ytterligere kan man si at en person kan ha en selvtilskrevet kurdisk identitet i kurdiske sammenhenger, for så å vise en tilskrevet identitet i det offent- lige rom (Akman 1995). Dette er en identitet som andre tilskriver deg, men som du ikke nødvendigvis føler deg komfortabel med.

Flyten av informasjon og kunnskap gjennom et virtuelt museum vil forhåpentligvis kunne gi bedre forutsetninger for at kurdisk kultur kan overleve i fremtiden. Et virtuelt museum vil bidra til å gjøre diasporasamfunn synlige, og bidra til å utvikle kunnskap mellom kurdere i diaspora og kurdere som bor $\mathrm{i}$ Kurdistan, mellom vertslandet og den aktuelle gruppen (her kurderne). På denne måten vil et online museum fungere som et transnasjonalt rom med plass for alle.

Mye arbeid gjenstår før det virtuelle museet kan bli en realitet. Data som samles inn må være maskinlesbare, og det må innhentes mer kunnskap om materialets opprinnelse og eksistens. Registrering av gjenstandene vil gi bedre oversikt og mulighet for å utvikle kunnskap omkring ulike fagfelt. Sist, men ikke minst skal det virtuelle museet samarbeide med internasjonale kulturelle institusjoner når det gjelder kunnskap og kompetanse på dette feltet. Det være seg institusjoner som spesifikt jobber med kurdisk kulturarv, men også andre aktører på feltet. Det er også avhengig av økonomisk støtte, slik at det er mulig å engasjere fagpersoner til å publisere websidene og drive museet online.

\section{HISTORISKE OG NÅTIDIGE KULTURMØTER MELLOM KURDERE OG NORDMENN}

I tillegg til å samle inn kurdiske gjenstander, annet materiale og personanekdoter er det lagt vekt på å utvikle kunnskap om kulturmøteprosesser, og erfaringer som kan knyttes til disse. I denne sammenheng er det særlig interaksjon mellom kurdere og nordmenn $\mathrm{i}$ fortid og nåtid det har vært fokusert på. Et slikt eksempel kan spores tilbake til vikingtiden, og 
handelsforbindelser med Midtøsten. Fra denne tiden er det funnet kurdiske marwandiske mynter både i Norge, Sverige og Danmark. Det største funnet er gjort på Gotland, der det ble funnet 90 slike mynter. ${ }^{8}$ Det finnes spor av vikingtokter $\mathrm{i}$ disse områdene tilbake til år 943 ved Berdas Port som ligger i det nåværende Azerbajan. Ifølge den arabiske historikeren Mukaddasi het en av Berdas porter "Kurdernes port".

Det viser seg at kulturmøter mellom nordmenn og kurdere også har funnet sted etter vikingtiden. Den norske sosialantropologen Fredrik Barth (1953) reiste flere ganger til Kurdistan, og er en av de første norske forskere som bruker denne betegnelsen, noe som har hatt stor betydning for kurdisk kulturarv. Fridtjof Nansen beskriver også møter med kurdere i forbindelse med reiser og arbeid i utlandet, blant annet kurdere i Tiflis, i SentralAsia. ${ }^{9}$

Det finnes også dokumentasjon på at norske misjonærer reiste til Kurdistan tidlig på 1900 tallet. Hensikten med deres arbeid var å tilfredsstille lokalbefolkningens åndelige og fysiske behov. I følge Naby (2006) var historikeren Ludwig Olsen Fossum (1879-1920) en av de første norskættede misjonærene som dro til Kurdistan (Urmia). Olsen Fossum er nevnt som den som forfattet det første tidsskrift på kurdisk. ${ }^{10}$ Det arbeidet han gjennomførte i de kurdiske områdene er i dag legendarisk. Hans omsorg for barn og enker, opprettelsen av et medisinsk og sosialt hjelpeapparat som ikke tidligere fantes, er trolig hans viktigste bidrag. Gjennom reisebeskrivelser, i dag en verdifull dokumentasjon, har misjonærene og andre utvidet kunnskapen om Mesopotamia, den kulturelle dynamikk og kulturmøter som har foregått i dette området.

Samtidsdokumentasjon om kulturmøter mellom kurdere og nordmenn i nåtid, er et annet mål for dokumentasjonsprosjektet. Nåtiden er lettere å dokumentere fordi det finnes redskap som letter arbeidet. Ikke minst har Statistisk Sentralbyrå (SSB) bidratt vesentlig i så måte. De første kurderne kom til Norge på 1970-tallet. Etter militærkuppet i Tyrkia i 1980, da store deler av venstresiden ble utryddet, var det mange kurdere som prøvde å komme til Skandinavias og til Norge som følge av politisk overvåkning og fare for fengsling. I nyere tid (etter 2003) har mange kurdiske flyktninger kommet fra Irak. Alle har historier å fortelle, alle har gjenstander, klær, musikk, bilder og minner. Disse er det interessant for ettertiden å få del i fordi de forteller en historie om disse kurdernes fortid, nåtid og deres tanker og håp om framtiden. Kurderne $\mathrm{i}$ Norge inngår daglig i mange ulike kulturmøter, formelle og uformelle; gjennom hele utdanningsløpet, i arbeids- og samfunnsliv, i kulturelle sammenhenger, i fagforeninger og i politiske partier. Mange driver aktiv politisk lobbying for å fremme kurdernes sak, men også innen kulturfeltet er kurderne aktivt tilstede for å representere sitt folk. Selv om kurderne har bodd i Norge i nærmere 40 år, finnes det lite dokumentasjon på livet i diaspora og det som finnes er mangelfullt. Prosjektet som er beskrevet her er en begynnelse, men er langt fra sluttført. Selv om grunnlaget for et norskkurdisk virtuelt museum er lagt gjennom NKKD, vil det kreve større ressurser, både $ø$ konomiske og faglige for å få det ferdigstilt til publisering på nettet.

\section{UTFORDRINGER I DOKUMENTASJONS ARBEIDET}

Som nevnt har det vært en stor utfordring å få tilgang til og oversikt over kurdisk kulturarv- 
materiale i diaspora, blant annet fordi kilder og opphav ofte er usikre eller ukjente. Det vil si at vi vet lite om hvem som har produsert materialet, hvor det kommer fra, hvem som ivaretar det, og eventuelt hvor materialet befinner seg i dag. Et gjennomgående trekk ved de kulturelle diasporainstitusjonene er begrenset kunnskap om kurdisk kulturarv, og gjenstander med kurdisk opprinnelse som befinner seg i diaspora.

Mange verdifulle gjenstander er hentet fra Kurdistan og brakt til Europa. De fleste av dem befinner seg i museumsinstitusjoner og er arkivert under de nasjonalstater kurderne bor. Mangelfull kunnskap om kurdiske gjenstander i de offisielle museumssamlingene gjør det vanskelig å registrere dem under korrekt kategori. Ikke minst har kunnskap om gjenstandene betydning når disse skal videreformidles til publikum. For prosjektet har det vært et detektivarbeid å identifisere de enkelte gjenstandene fordi dette krever spesiell kompetanse og god kunnskap om kurdisk historie. Det at kurderne er delt mellom fire stater, gjør det vanskelig å skille ut de gjenstander som faktisk er kurdiske. Karakteristisk for de ulike museene vi har vært i kontakt med er at gjenstander ofte er kategorisert i henhold til regional og statlig tilhørighet, eller til en verdensdel eller religion (islam, kristendommen). For å gi et eksempel: British Museum katalogiserer gjenstander med utgangspunkt i geografiske referanser og tilhørigheter. Det man da risikerer er at en kurdisk gjenstand kategoriseres som iransk, irakisk, tyrkisk eller syrisk, eller ennå mer generelt, som en gjenstand fra Mesopotamia.

Dersom vi søker på navnet "Kurdistan" på COMPASS $^{11}$ (Collections Multimedia Public Access System), selve ryggraden i British $\mathrm{Mu}-$ seums digitale samlinger, dukker det opp en påfugl i stål. Teksten forteller oss at påfuglen

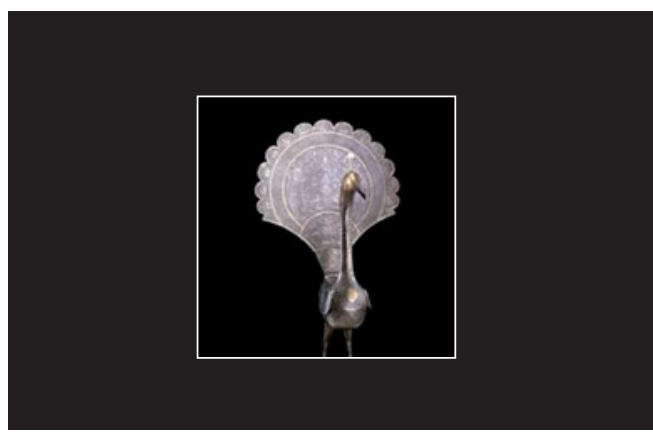

Figur 1: Kurdisk påfugl i stål, British Museum. Photo: Haci Akman.

kommer fra Iran, og kan dateres tilbake til det 1900 århundre etter Kristus. Vi får vite at påfuglen er et symbol på skjønnhet og nytelse i den islamske verden. Derfor er den katalogisert som iransk under avdeling for islamske gjenstander.

Denne påfuglen har imidlertid en helt spesiell stilling hos kurderne fordi den er et symbol på kurdernes eldste religion Yezidi. ${ }^{12}$ Yezidiene har vært et yndet forskningstema blant orientalister. En grunn er at de av mange muslimer og kristne har blitt skildret som djeveldyrkere, en forståelse som finnes også i vestlig populærkultur. En årsak kan være at yezidiene ber til påfuglsengelen Melek Tawus, identisk med engelen Lucifer. Kurderne, som statløse uten definisjonsmakt på dette området, vil derfor ikke vinne frem med krav om at påfuglen har opprinnelse i kurdisk kultur, den tilskrives i stedet den staten der kurderne bor. Dette er en form for kolonisering, ikke bare av folket og deres territorium, men av kulturelle tradisjoner, gjenstander og elementer som er spesifikke for den aktuelle kulturen (Anholm 2001).

En annen utfordring i dokumentasjonsprosjektet var å hente informasjon fra private ar- 
kiv og samlinger. I perioden 1980 og frem til i dag har en rekke intellektuelle kurdiske kulturpersonligheter etablert seg i ulike europeiske land. De fleste er tvunget i eksil på grunn av sitt arbeid for vitenskapelig og historisk bevisstgjøring av kurdernes opphav, og sist men ikke minst har de vært forkjempere for kurdisk språk og kultur. Kurdiske informanter som inngår i materialet ser på diaspora som en gevinst, fordi den har gitt dem mulighet til å uttrykke sin identitet, uten å frykte for sitt liv. Mange av disse tok med seg gjenstander, billedmateriale, litteratur, fortellinger, minner og kunnskap om kurdisk kultur - i all sin mangfoldighet. Også kjente kurdiske forfattere som Mehmed Uzun, Mehmed Lewendi, Rohat Alakom, og Mehmed Emin Borzarlan har bidratt til å gjøre kurdisk kulturarv kjent i og utenfor Norden. ${ }^{13}$ Alle disse er eksempler på hvordan enkeltpersoner gjennom sitt arbeid med tiden kan ha opprettet større og mindre private samlinger bestånde av gamle kurdiske kulturelementer; manuskript og gamle tidsskrift, foto, publikasjoner, og gjenstander.

Selv om informantene i prosjektet opplever at diaspora er en ressurs, er den gamle frykten fortsatt i noen grad tilstede. Noen av dem ga

Figur 2: Serefname. Photo: Haci Akman.

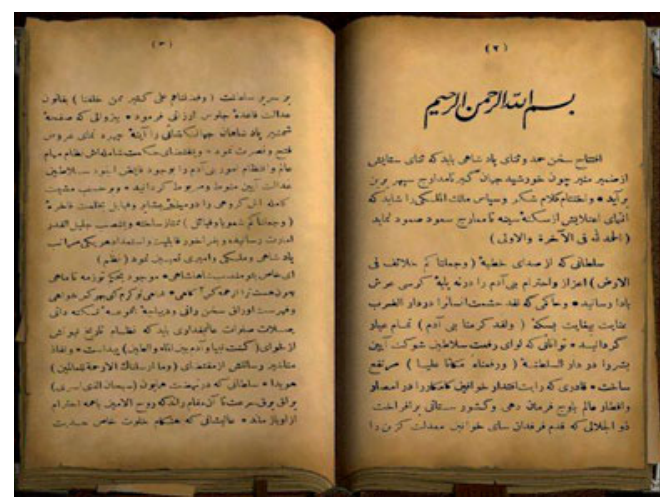

uttrykk for at å gi fra seg gjenstander til museumsformål, eller å la dem avfotografere, kunne være et litt for stort skritt å ta. Gammel usikkerhet overfor personer og institusjoner er fortsatt tilstede. Politisk, sosial og kulturell undertrykking og forfølgelse gjør at de er nøler med å levere fra seg informasjon og kunnskap om det materialet de sitter inne med. Mange har også vansker med å fortelle sine livshistorier, de er fremdeles for vonde å snakke om, eller de er redd de uforvarende kan komme til å nevne andre personer. Om andres navn røpes, kan disse få problemer med myndighetene. Ulrika Wolf-Knuts og Lena Marander-Eklund (1995) er inne på noe liknende når de drøfter etiske spørsmål i forbindelse med bruk av personanekdoter. Når man samler inn, arkiverer, redigerer og publiserer personlige minner der personanekdoter er sterkt tilstede, skal man gå varsomt frem og i nært samarbeid med den som opplever at de eier "minnene". Det er viktig å huske på at arbeid og formidling av kurdisk kultur er årsaken til at disse informantene lever i eksil. Dokumentasjon av kurdisk kulturarv avhenger derfor av den grad av tillit som etableres mellom forsker og informant og et samarbeid om hvordan dette materialet skal brukes, oppbevares og formidles.

En annen utfordring knytter seg til innhenting av dokumentasjon av politisk ladet kulturarvmateriale. Dette kan være ideer som knytter sammen tanken om en felles nasjon og som fungerer som en historisk referanse til et folk eller en etnisk gruppe. Et eksempel på dette er det historiske verket Serefname (1597).

Hvordan Serefname kom til England, har vi ingen kunnskap om. Originalmanuskriptet sies blant kurdere å være oppbevart ved biblioteket Bodleian, ${ }^{14}$ ved Universitetet i Oxford. Det ble senere, i følge Mehmed Emin Bozars- 
78 lan (1990, s. 5), overført til British Museum, og dernest til British Library. Dette avkreftes imidlertid i samtale med en konservator ${ }^{15}$ ved British Museum:

It is doubtful whether the original manuscript of Sharaf Khan's Sharafnamah exists anywhere. The Library has four copies, none of which date from any time close to the author's lifetime, which is undated but probably early 19 th century.

Kurator mener at verket er skrevet på persisk, og beretter historien om folk i Midtøsten, ikke om kurderne spesielt. I følge Krabbe (2005, s. 8) er det imidlertid en sterk forbindelse mellom kulturarv og politikk, og at stater kanskje får en legitimert eiendomsrett til de kulturer som eksisterer innenfor statens geografiske grenser. Jeg går ikke nærmere inn på dette, men eksempelet viser at det kan være vanskelig å dokumentere gjenstander og andre kulturelementer tilhørende statsløse grupper og folk, da disse gjerne kategoriseres i henhold til de stater og nasjoner de lever i.

De dokumentarfilmer som er samlet inn eller laget spesielt for prosjektet, tar utgangspunkt i ulike aspekter ved den kurdiske kulturen. De formidler alt fra matkultur, håndverkstradisjoner, dans og Newroz-feiring. ${ }^{16}$ For å gi et innblikk i produksjon og reproduksjon av kurdisk kultur, var det et mål å filme kurdiske tradisjoner i norske kontekster, og gi eksempler på rekonstruksjoner hvor elementer fra kurdisk matlaging kombineres med norske mattradisjoner i kurdiske hjem. Her er det viktig at de som deltar selv velger hva de ønsker å formidle av mattradisjoner. Informantene har ulik kunnskap og erfaringer om alt fra mattradisjoner og feiringer til historiske hendelser. Det er viktig å fange et så bredt spekter av kulturelle elementer som mulig, og kombi- nere det med annen type faktakunnskap som skal formidles. Ikke mindre viktig vil det være å formidle hvilken betydning ulike aspekter ved kulturen har for den enkelte. Diasporatilværelsen, med sin spredte karakter, drar ulike symbolske og kulturelle rammer rundt for eksempel kulturell identitet, men kan også være en fellesnevner.

Fotografi er et kulturarvmateriale med stort narrativt potensial. Fotografiet representerer begivenheter, tradisjoner og kulturell identitet. Dersom en går dypere inn i materialet, kan også andre aspekt knyttes til fotografiet; stedsidentitet, fortid og nåtid. Et eksempel er foto av en Newroz-feiring. Det forteller om en nasjonal feiring, men har en symbolsk betydning langt utover dette. Derfor vil bildet ikke være fullstendig uten sammen med en forklarende tekst, gjerne kombinert med opptak av fortellinger om Newroz, både legenden og historien bak.

For kurdere vil møte med hjemlandet gjennom et virtuelt museum skape nasjonal stolthet og identifikasjon med et transnasjonalt kurdisk samfunn, for nordmenn vil opplevelsen av å bli ønsket velkommen gjennom et virtuelt museum være et møte med en form for "autentisk Kurdistan".

\section{HVA HAR VI FUNNET?}

Et sentralt funn i dokumentasjonsprosjektet er at det i særlig grad er gjenstander og artefakter som bidrar til å understreke kurdernes tilknytning til et sted. Mange intellektuelle (forskere, forfattere, kunstnere) betrakter diaspora som en ressurs og gevinst, et sted der den kurdiske bevisstheten har våknet. Diaspora er et rom med muligheter for formidling og videreutvikling av kurdisk kulturarv. Det er kanskje motsetningsfullt når noen av dem nøler med å 
låne ut eller gi fra seg noe av det de har samlet, eller fortelle historien om seg selv. Dette må imidlertid ses i sammenheng med at den sårbare politiske bakgrunnen mange av dem kommer fra.

Da prosjektet startet opp hadde vi ingen idé om hva vi skulle finne, eller om det overhodet fantes noe vi kunne kalle kulturarvmateriale i de diasporaland vi besøkte (Norge, Sverige, England og Belgia). Det viste seg at opptil flere informanter satt på verdifulle samlinger, som var relevante og interessante å registrere. Mange kulturarvkilder som kun var på folkemunne (muntlige), fikk en skriftlig språkdrakt i diaspora. Slik sett har diaspora på mange måter tatt kurdisk kulturarv til et nytt nivå.

Verdifulle kurdiske gjenstander som er brakt til Europa av vestlige vitenskapsmenn, misjonærer og oppdagere, og som i dag ligger i katalogene til kjente europeiske museumsinstitusjoner og bibliotek, er katalogisert under de land/stater kurderne er delt mellom. Det litterære verket "Serefname" og "Påfuglen" er eksempler på dette. Dette kan i vid forstand forstås som kolonisering av kurdisk kulturarv, $i$ alle fall deler av den.

Det vi også ser, og som kan betraktes som et funn i denne sammenheng, er at kulturforeninger ofte fungerer som en erstatning for formelle kurdiske kulturinstitusjoner. En viktig funksjon som slike foreninger har, er å være et samlingssted for kurdere fra alle deler og skape en opplevelse av fellesskap og kollektiv identitet. Kurderne har levd splittet i bortimot hundre år. I perioder har de hatt lite med hverandre å gjøre, i andre perioder har det vært fiendskap mellom dem. Diaspora har imidlertid bidratt til å føre kurderne nærmere hverandre. Kulturforeningene bringer kurdere sammen for felles arrangementer, som for eksempel den kurdiske nasjonaldagen (nyttår)
Newroz. Kurdiske musikere ${ }^{17}$ i diaspora har gjennom sin musikk og kurdiske språk brakt stolthet og et samhold som mange ikke har opplevd før. Dette har medført at kurderne i diaspora mer enn noen gang ønsker å være $\mathrm{i}$ kontakt med hjemlandet, lære med om sin bakgrunn og opprettholde språket og kulturelle tradisjoner. Mange unge i diaspora, for eksempel her i Norge, er sterkt knyttet til vertslandet, men er likevel orientert mot sitt kurdiske hjemland. Et norsk-kurdisk virtuelt museum vil underbygge begge disse tilhørighetene.

\section{KONKLUSJON OG VEIEN VIDERE}

I denne artikkelen har jeg presentert prosjektet Norsk-kurdisk kulturarv dokumentasjonsprosjekt (2004-2007). Prosjektet består av to faser. I første fase har vi hatt som intensjon å dokumentere og samle inn kulturarvmateriale i diaspora. En del av dette har vært å se på kulturmøter mellom nordmenn i fortid og nåtid. En annen del har vært å undersøke om det finnes liknende prosjekt internasjonalt, i dette tilfellet har vi sett på jødisk og afrikansk diaspora i England. Disse erfaringene var viktige, men er ikke gått i dybden av her. De gjenstander og det datamateriale som er samlet inn vil utgjøre fundamentet i kurdisk-norsk virtuelt museum, et online museum som skal etableres på sikt.

Noen av de utfordringer prosjektledelsen støtte på under feltarbeidet og mulige årsaker til dem, er drøftet i artikkelen, det er også viktigheten av å dokumentere en statsløs folkegruppes (kurdernes) kulturarv i diaspora, og hvorfor det er viktig at den bevares og formidles videre. Kurdernes kulturarv er splittet som kurderne selv. Det kurdiske folk bor i dag i fire stater; Tyrkia, Iran, Irak og Syria. I tre av disse 
80 er det fortsatt undertrykket og forfulgt (unntaket er Irak etter Saddam Husseins fall i 2003). Kurdisk kulturarv lider under dette. I alle delene finnes uerstattelige kurdiske kulturskatter som forfaller som følge av myndighetenes vanskjøtsel. På samme tid hindres kurderne selv i å opprette fysiske institusjoner der kulturarvgjenstander kan stilles ut. Dette er en måte å usynliggjøre og fornekte kurdisk identitet og kultur. I diaspora har intellektuelle og andre kulturpersonligheter selv tatt på seg å samle inn og ivareta kurdisk kulturarv, men det kan i verste fall bety at historiske kulturelle gjenstander, skriftlige dokumenter, musikk, kunst og andre artefakter privatiseres og gjemmes bort. Som følge av den historiske sårbarheten mange kurdere i diaspora lever med, møtte vi som forskere også en viss motstand fra eierne om å utlevere, eller snakke om kulturarvmaterialets opprinnelse og bakgrunn. Det var også vanskelig for flere informanter å fortelle historiene sine, igjen grunnet tvil og mistro. I slike sårbare felt er det viktig å bruke tid på å opp-rette tillit mellom partene.

En videreføring av prosjektet er å opprette et kurdisk-norsk virtuelt museum, der kulturarvmateriale fra dokumentasjonsprosjektet legges ut virtuelt. Mye kulturarvmateriale, materielt og immaterielt er i dag i diaspora. Det er viktig for et statsløst folk, som ikke har egne institusjoner, å finne muligheter og alternativer som oppveier for mangelen på slike. Noe av oppbevaringen og formidlingen av kulturarvstoff ivaretas i dag av private samlinger og kulturforeninger. Dette er imidlertid ikke tilstrekkelig, fordi det mangler systematikk og faglighet rundt spørsmål om innsamling, kategorisering, arkivering og oppbevaring. Når kurderne ikke kan opprette egne fysiske institusjoner, vil et virtuelt museum være et godt alternativ. Realiseringen av et slikt til- tak vil imidlertid kreve ressurser $\mathrm{i}$ form av økonomiske midler til å opprette det og fagpersoner til å følge opp og drive det videre.

\section{NOTER}

1. Prosjektet har to faser. I fase en, dokumentasjonsfasen (2004-2007), besto prosjektledelsen av artikkelforfatter, samt to vitenskapelige assistenter (Janne Mellingen og Lise Johansen). I fase to, tilrettelegging for virtuelt museum (2007-2009) var kun tilknyttet en vitenskapelig assistent, Janne Mellingen.

2. Norsk Kulturråd: http://www.norskkulturrad.no/

3. Norsk Organisasjon for Statsløse Mennesker; http://www.stateless.no/page24.php

4. I følge Özoglu (1996, p. 8) er kurdiske emirater annerledes enn stammen i forhold til dets størrelse og heterogenitet, opprinnelse og klassekomposisjon, solidaritet med andre og den tette forbindelsen til staten. Det kurdiske emiratet består av stammer, og ikke-stamme grupper som snakker ulike dialekter. Den overordnete leder for emiratet er Mir, som har stor militær makt og lever i et bevoktet område (fort).

5. Pluralisme betyr at de mange grunnsyn som eksisterer i samfunnet er like mye verdt. I et pluralistisk samfunn strider ulike grunnsyn noen ganger mot hverandre. Utfordringen er å finne en balanse mellom de ulike syn, og at alle får sin stemme hørt.

6. Liknende erfaringer er gjort ved Jewish Museum i Camden, og Finchley, og ved Black Cultural Heritage Archives i Brixton (Black Cultural Archive; $\mathrm{BCA}$ ), som var de prosjektene prosjektledelsen oppsøkte.

7. Nord (Tyrkia), sør (Nord Irak), øst (Iran) og vest (Syria).

8. De kurdiske Marwandiske myntene er en del av et større skattefunn fra gården Oldøy, gnr 110, 
Suldal kommune. Funnet er utstilt ved arkeologisk museum i Stavanger og har museumsnr. S3400. Datering: - Nedlagt etter år 1051.

9. Fra begynnelsen av 1900 tallet arbeider Fridtjof Nansen som den første høykommissær. En av oppgavene var å bringe hjem krigsfanger. I 1925 er han Folkeforbundets utsending i Armenia og Kaukasus. I den forbindelse skrev han boken Gjennom Armenia (1927), et arbeid som brakte ham i kontakt med kurderne i området.

10. The First Kurdish Periodical in Iran: http://www.aina.org/reports/fkpir.htm

11. En database som inneholder en samling gjenstander fra British Museums samlinger. http:// www.artcyclopedia.com/feature-2002-01.htm

12. Yezidiismen, på kurdisk Êzîdîtî, er særlig utbredt blant kurderne og er lokalisert i to områder i nord Irak. Det bor tilhengere i alle de delene der kurderne bor og også i diasporasamfunn, der religionen har tatt seg opp de senere år.

13. Kurdiske forlag som APEC og Sara Distribution er eksempel på institusjoner som forfatternes arbeid kjent.

14. Bodleian Library kan besøkes på http://www.bodleian.ox.ac.uk/

15. Dr. Muhammed Isa Waley. Kurator for tyrkiske og persiske samlinger. Intervju 2007.

16. Kurdisk nyttår som feires årlig ved vårjevndøgn den 21. mars.

17. Siwan Perwer og Siwan Haco er eksempler i så henseende.

\section{REFERANSER}

Akman, H. (1995). Landflyktighet. En etnologisk undersøkelse av vietnamesiske flyktninger i eksil. Bergen: Migrasjonsforlaget.

Akman, H. (2002). Honor, Feuding, and National Fragmentation in Kurdistan. In T. Aase (Ed.). Tournaments of Power: Honor and Revenge in the
Contemporary World (pp. 101-114). Aldershot,
Anholm, M. (2001). Jesid-kurder. Stockholm: Apec Förlag.

Barth, F. (1953). Principles of social organization in South Kurdistan. Oslo: Universitetets Etnografiske Museum.

Braziel, J. E., \& Mannur, A. (2003). Nation, Migration, Globalization: Points of Contention in Diaspora Studies, J. E. Brazier, \& A. Mannur (Eds.) Theorizing diaspora: a reader. Blackwell Publishing.

Brah, A. (1996). Cartographies of Diaspora: Contesting Identities. New York: Routledge.

Brubaker, R. (2005). The 'diaspora' diaspora, Ethnic and Racial studies, 28: 1-19.

Cohen, A. (1997). Global Diasporas: An Introduction. Seattle, WA: University of Washington Press.

Hassanpour, A. (2003). Diaspora, homeland and communication technologies. In H. K. Karim (Ed.), The Media of Diaspora (pp.76-88). London, New York: Routledge, Taylor \& Francis Group.

Hoptman, G. (1992). The Virtual Museum and Related Epistemological Concerns. In E. Barrett (Ed.). Sociomedia. Multimedia, Hypermedia and the Social Construction of Knowledge.Ed. Edward Barrett: Cambridge, Mass.: MIT-Press. S. 141159.

Izady, Mehrdad R (1992). The Kurd: a concise handbook. Washington, DC \& London: Taylor \& Francis, Inc.

Krabbe, B.C. (2005). World Heritage. In H. Akman \& O. Stoknes (Eds.). The Cultural Heritage of the Kurds. University of Bergen: BRIC. Center for Development Studies.

Massey, D.B. (1994). Space, place, and gender. Minneapolis: University of Minnesota Press.

McDowell, D. (2000). A Modern History of the Kurds (2nd edition). New York, NY: Taurus \& Co, Ltd. McKenzie, J. (1997). Building a Virtual Museums 
Community. Paper presented at the Museums \& The Web Conference March 16-19, 1997 Los Angeles, California. Internet, URL = http://fromnowon.org/museum/museweb.html.

Naby, E. (2006). The First Kurdish Periodical in Iran. Journal of Kurdish Studies Vol. 20, nos. $1 \& 2$, pp. 215-233.

Nansen, F. (1927). Gjennem Armenia. Oslo: Jacob Dybwads Forlag.

Özuglu, H. (1996). State-Tribe Relations: Kurdish Tribalism in the 16th- and 17th-Century Ottoman Empire. British Journal of Middle Eastern Studies, 23 (1), 5-27. Retrieved 23.4.2008, from http://www.jstor.org/sici?sici=13530194(199605) 23\%3A1\%3C5\%3ASRKTIT\%3E2.0. CO $\% 3 \mathrm{~B} 2-\mathrm{B}$

Robertson, A."Narrativana lys", i Göran Bergström and Kristina Boréus, red. Textens mening och makt. Lund: Studentlitteratur, 2005.

Serefhan (1597). Serefname. Oversatt av M. E. Bozarslan (1990) (3. utgave). Istanbul: Hasat Yayinlari.

Schweibenz, W. (1998). The "Virtual Museum": New Perspectives For Museums to Present Objects and Information Using the Internet a Knowledge Base and Communication System. In H. H. Zimmermann \& V. Schramm (eds): Knowledge Management und Kommunikationssysteme. Workflow Management, Multimedia, Knowledge Transfer.Proceedings des 6. Internationalen Symposiums für Informationswissenschaft (ISI '98) Prag, 3.-7. November 1998. (Schriften zur Informationswissenschaft 34). Konstanz: UKV. S. 185-200. Hentet 20.6.2011 fra: http://is.unisb.de/projekte/sonstige/museum/virtual_museum_isi98

Sheffer, G. (2003). Diaspora Politics: At Home Abroad. Cambridge: Cambridge University Press.

Yildiz, K. (2005). The Kurds in Turkey. EU accession and Human Rights. London, Ann Arbor, MI, in association with Kurdish Human Rights Project: Pluto Press.
Walbeck, Ö.R. (2002). The concept of diaspora as an analytical tool in the study of refugee communities. Journal of Ethnic and Migration Studies, Vol. 28, No. 2, pp. 221-238.

Westrheim, K. (2005). Cultural Identity and Oppression Experienced through the Kurdish Liberation Struggle. In H. Akman \& O. Stoknes (Eds.). The Cultural Heritage of the Kurds (pp. 105-128). University of Bergen: BRIC. Center for Development Studies.

Westrheim, K. (2009). Education in a Political Context. A study of knowledge processes and learning sites in the PKK. Faculty of Psychology. Bergen, University of Bergen Dissertation for the Degree Philosophiae Doctor (PhD).

Wolf-Knuts, U. \& Marander-Eklund, L. (1995):

Etiska synspunkter i samband med användingen av personanekdoter. Nord Nytt 60. s 39-49. 11 s.

\section{*Haci Akman}

Adresse: Allegaten 38, 5007 Bergen, Norge

E-mail:Haci.akman@ahkr.uib.no 